\title{
Five new species of philometrid nematodes (Philometridae) from marine fishes off Java, Indonesia
}

\author{
František Moravec $^{1}$, Thorsten Walter ${ }^{2}$ and Asri Trisnani Yuniar ${ }^{3}$ \\ ${ }^{1}$ Institute of Parasitology, Biology Centre of the Academy of Sciences of the Czech Republic, Branišovská 31, 37005 České \\ Budějovice, Czech Republic; \\ ${ }^{2}$ Ostseestation Priwall, Am Priwallhafen 10, 23570 Lübeck-Travemünde, Germany; \\ ${ }^{3}$ Aquatic Animal Health Center, Central Proteinaprima, Tbk. Jalan Dupak Rukun No. 81 Surabaya, Indonesia
}

\begin{abstract}
Based on light and scanning electron microscopical studies, the following five species of the Philometridae (Nematoda: Dracunculoidea) are described from female specimens collected from marine fishes off the southwestern coast of Java, Indonesia: Philometra lobotidis sp. n. from the abdominal cavity of the Atlantic tripletail Lobotes surinamensis (Bloch) (Lobotidae, Perciformes); Philometra javaensis sp. n. from the abdominal cavity of the immaculate puffer Arothron immaculatus (Bloch et Schneider) (Tetraodontidae, Tetraodontiformes); Philometra psettoditis sp. $\mathrm{n}$. from the musculature of the Indian spiny turbot Psettodes erumei (Bloch et Schneider) (Psettodidae, Pleuronectiformes); Philometroides indonesiensis sp. n. from the musculature of the hound needlefish Tylosurus crocodilus crocodilus (Péron et Lesueur) (Belonidae, Beloniformes); and Philometroides trichiuri sp. $\mathrm{n}$. from the dorsal fin of the largehead hairtail Trichiurus lepturus Linnaeus (type host) and the savalai hairtail Lepturacanthus savala (Cuvier) (both Trichiuridae, Perciformes). All these new species are distinguished from their congeners parasitizing marine fishes by morphological (mainly the shape and structure of the cephalic and caudal ends and of the oesophagus) and biometrical features. Besides previously known Philometra pellucida (Jägerskiöld, 1893) and Philometra ocularis Moravec, Ogawa, Suzuki, Miyazaki et Donai, 2002, they are the only nominal philometrid species recorded from Indonesian waters.
\end{abstract}

Keywords: parasitic nematodes, Philometra, Philometroides, taxonomy, teleost fish

Philometrid nematodes (Philometridae) are usually pathogenic parasites occurring frequently in commercially important wild or cultured fish hosts (Moravec 2006). Due to some morphological and biological peculiarities, most of them are known only by their large-sized females. The knowledge of the fauna of these nematodes parasitizing marine fishes in Indonesian waters remains fragmentary. Although there are few published and unpublished records of Philometra sp. or Philometroides sp. in Indonesian marine fishes (e.g., Jacob and Palm 2006, Rückert et al. 2009, 2010, Kleinertz 2010), the only known nominal philometrid species from this region are Philometra pellucida (Jägerskiöld, 1893), a parasite of the abdominal cavity of the starry toadfish Arothron stellatus (Bloch et Schneider) in the Java Sea (Jägerskiöld 1893, 1894, Moravec 2006), and Philometra ocularis Moravec, Ogawa, Suzuki, Miyazaki et Donai, 2002, a parasite recorded from the oculo-orbit of the brown-marbled grouper Epinephelus fuscoguttatus (Forsskål) in the Lampung Bay, Sumatra (Rückert et al. 2010).

During parasitological investigations on some marine fishes off the southwestern coast of Java, Indonesia, car- ried out in 2000-2002, philometrid nematodes (only females) were found in six species of fishes belonging to Beloniformes (1), Perciformes (3), Pleuronectiformes (1) and Tetraodontiformes (1). Their closer examination revealed that all of them are representatives of five new species belonging to Philometra Costa, 1845 or Philometroides Yamaguti, 1935; these are described herein.

\section{MATERIALS AND METHODS}

The examined fishes were caught by artisanal fishermen and obtained from local fish dealers in Pelabuhan Ratu, southern Java coast, Indonesia $\left(06^{\circ} 59^{\prime} \mathrm{S}, 106^{\circ} 32^{\prime} \mathrm{E}\right)$ in the period from March 2000 to April 2002. Only fresh fish specimens were bought and directly transported on ice to the nearby marine biological station of the Bogor Agricultural University. Fishes were examined macroscopically to detect infections of female nematodes. Scalpels and forceps were used to cut or tear host tissue away from parasites so that they could be collected gently with forceps. The main interest of the research project was to study fish parasitic crustaceans, acanthocephalans and trypanorhynch cestodes; some nematodes and specimens of other parasite groups were also collected beside, however, without quantitative data. 
During this study, philometrid nematodes were recorded from the following six fish species: Beloniformes: hound needlefish Tylosurus crocodilus crocodilus (Péron et Lesueur) (Belonidae); Perciformes: tripletail Lobotes surinamensis (Bloch) (Lobotidae), savalai hairtail Lepturacanthus savala (Cuvier) and largehead hairtail Trichiurus lepturus Linnaeus (both Trichiuridae); Pleuronectiformes: Indian spiny turbot Psettodes erumei (Bloch et Schneider) (Psettodidae); Tetraodontiformes: immaculate puffer Arothron immaculatus (Bloch et Schneider) (Tetraodontidae).

The nematodes recovered were washed in physiological saline and then fixed in cold $70 \%$ ethanol. For light microscopy (LM) examination, the nematodes were cleared with glycerine. Drawings were made with the aid of a Zeiss drawing attachment. Specimens used for scanning electron microscopy (SEM) were postfixed in $1 \%$ osmium tetroxide (in phosphate buffer), dehydrated through a graded acetone series, critical-point-dried and sputter-coated with gold; they were examined using a JEOL JSM-7401F scanning electron microscope at an accelerating voltage of $4 \mathrm{kV}$, GB low mode. All measurements are in micrometres unless otherwise indicated. The names of fishes follow FishBase (Froese and Pauly 2011).

\section{RESULTS AND DISCUSSION}

\section{Family Philometridae Baylis et Daubney, 1926}

\section{Philometra lobotidis sp. n.}

Figs. 1, 2

Description of female (5 gravid specimens, measurements of holotype in parentheses; measurements of 1 smallest subgravid specimen in brackets): Body of fixed specimens yellowish, with smooth cuticle; body length 112-220 (220) [56] mm, maximum width 1.31-1.66 (1.50) $[0.61] \mathrm{mm}$, its maximum width/body length ratio 1:81-147 (1:147) [1:92]; posterior part of body narrower than anterior part. Width of cephalic end 272-340 (340) [204], of caudal end 177-340 (340) [122]. Cephalic end rounded, cephalic papillae very small, indistinct when viewed laterally (Fig. 1A,D). Oral aperture rather small, almost circular, surrounded by four pairs of submedian cephalic papillae of external circle and six single papillae (two lateral and four submedian) of internal circle (Figs. 1B, 2A,B). Amphids indistinct. Bottom of mouth formed by flat surfaces of three oesophageal sectors. Oesophagus 2.29-2.61 (2.61) [1.67] mm long, sometimes S-shaped, representing 1-2 (1) [3]\% of body length; anterior bulbous inflation well developed, markedly broad, 163-190 (177) [122] long and 218-258 (258) [149] wide. Oesophageal gland conspicuously large, opening into oesophagus just posterior to nerve ring; large cell nucleus at about middle of gland, 1.22-1.62 (1.62) [1.13] mm from anterior extremity. Nerve ring 299-367 (313) [218] from anterior end of body (Fig. 1A,D,G). Small ventriculus present, 41-54 (41) [27] long and 82-95 (82) [57] wide (Fig. $1 \mathrm{~A}, \mathrm{H}, \mathrm{G})$. Oesophagus opening into intestine through distinct valve (Fig. 1H). Intestine brown, relatively narrow at anterior end, ending blindly; its posterior end narrow, attached by ligament ventrally to body wall near caudal end; length of ligament 272-1,525 (340) [313]. Vulva and anus absent. Ovaries long, narrow, reflected, situated near body ends. Uterus occupying most space of body, filled with numerous larvae and eggs (Fig. 1A,C,F,G). Larvae from uterus 420-426 (not measured in holotype) long, maximum width 15 ; length of their oesophagus 105-108, representing $25 \%$ of body length; sharply pointed tail $60-78$ long, representing $15-18 \%$ of body length (Fig. $1 \mathrm{E})$. Posterior end of adults rounded, without any caudal projections (Fig. 1C,F).

Male: Unknown.

Ty p e host: Atlantic tripletail, Lobotes surinamensis (Bloch) (Lobotidae, Perciformes) (body length $47-49 \mathrm{~cm}$ ).

Site of infection: Abdominal cavity.

Type locality: Indian Ocean off Pelabuhan Ratu, south coast of western Java, Indonesia (holotype collected 1 October 2000, other specimens 18 June 2001).

Prevalence and intensity: 2 fish infected/5 fish examined; 1 and 13 specimens.

Deposition of type specimens: Holotype(MZBNa 515) and 5 paratypes (MZBNa 516) in the Museum Zoologi Bogor, Lembaga Ilmu Pengetahuan Indonesia, Cibinong, Indonesia. One paratype (N-984) in the Institute of Parasitology, Biology Centre, Academy of Sciences of the Czech Republic, České Budějovice, Czech Republic.

Etymology: The specific name of this nematode relates to the genitive form of the generic name of the host.

Remarks. Philometrids exhibit a rather high degree of host specificity (Rasheed 1963, Ivashkin et al. 1971, Moravec 2006) and individual species are characterized by their location in the host, particularly that of gravid females (Moravec 2004, Moravec et al. 2008). Moravec et al. (2008) reported a total of 17 species of Philometra the gravid females of which are parasitic in the body cavity of marine and brackish-water fishes, and provided a key to these species. However, an additional two species have been described since: Philometra gymnothoracis Moravec et de Buron, 2009 from the abdominal cavity of the spotted moray Gymnothorax moringa (Cuvier) (Muraenidae) off the western North Atlantic coast and $P$. spicarae Moravec, Gaglio, Giannetto et Marino, 2010 from the abdominal cavity of the picarel Spicara smaris (Linnaeus) (Centracanthidae) from the Ionian Sea off Sicily, Italy (Moravec and de Buron 2009, Moravec et al. 2010).

Of the above-mentioned species, only Philometra pellucida (Jägerskiöld, 1893) and P. obladae Moravec, Gaglio, Panebianco et Giannetto, 2008 have gravid females with a well-developed anterior oesophageal inflation, the posterior end of body without caudal projections and the body length exceeding $110 \mathrm{~mm}$, resembling thus the new species. However, in contrast to P. lobotidis sp. n., both species have the oesophageal gland poorly developed and indistinct (vs. oesophageal gland markedly large) and their caudal ends are broad (vs. obtusely conical). 

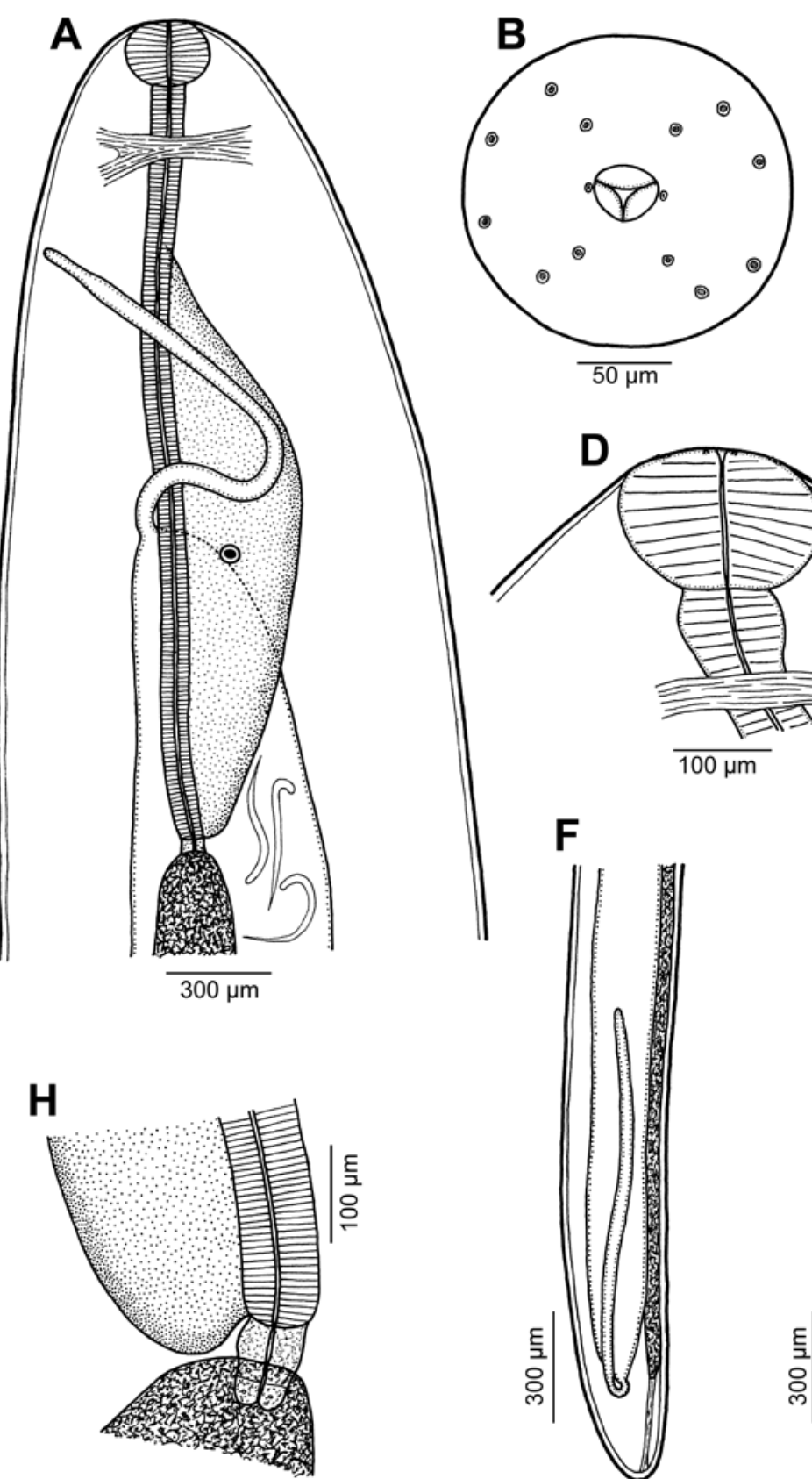

C
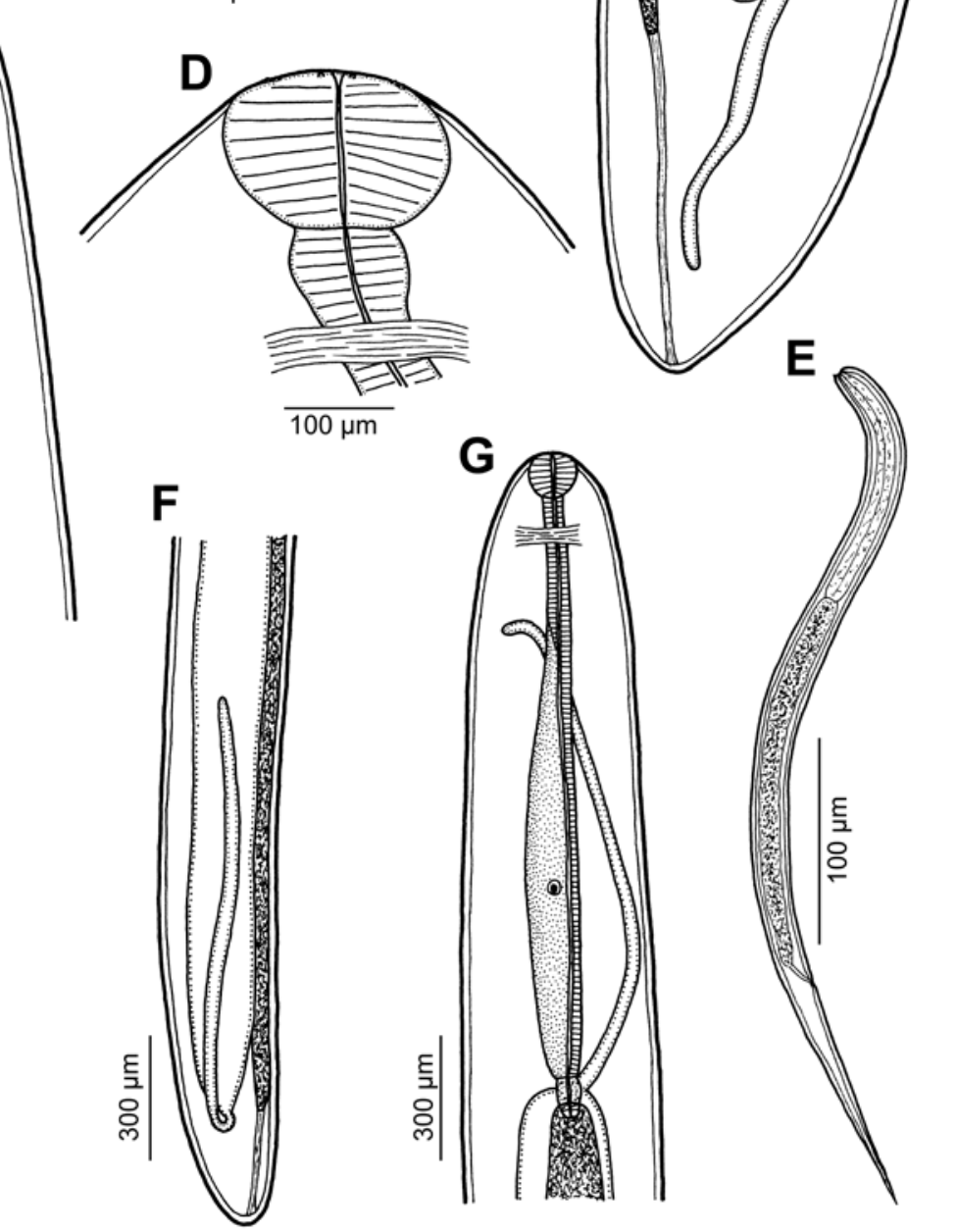

Fig. 1. Philometra lobotidis sp. n., female. A - anterior end of gravid specimen, lateral view; $\mathbf{B}$ - cephalic end of gravid specimen, apical view; $\mathbf{C}$ - posterior end of gravid specimen, lateral view; $\mathbf{D}$ - cephalic end of gravid specimen, lateral view; $\mathbf{E}$ - larva from uterus, lateral view; F, G - posterior and anterior ends of nongravid specimen, lateral views; $\mathbf{H}$ - oesophago-intestinal junction of gravid specimen, lateral view.

Moreover, the shape of the anterior oesophageal inflation and its structure of $P$. pellucida are different (inflation funnel-shaped, with spacious lumen vs. transverse-oval, with narrow lumen). The length of oesophagus in $P$. lobotidis sp. n. represents $1-2 \%$ of the body length of gravid female, but only $0.4 \%$ in $P$. obladae. These species also differ in the family of hosts: whereas $P$. pellucida is the parasite of fishes of the family Tetraodontidae and $P$. ob- ladae of the Sparidae (Jägerskiöld 1894, Moravec 2006, Moravec et al. 2008), the host of P. lobotidis belongs to the family Lobotidae.

To date, the only species of Philometra reported from fishes of the family Lobotidae is $P$. globiceps (Rudolphi, 1819). This gonad-infecting parasite of Uranoscopus scaber Linnaeus (Uranoscopidae) (type host) and some other fishes in the seas of the Mediterranean region and 


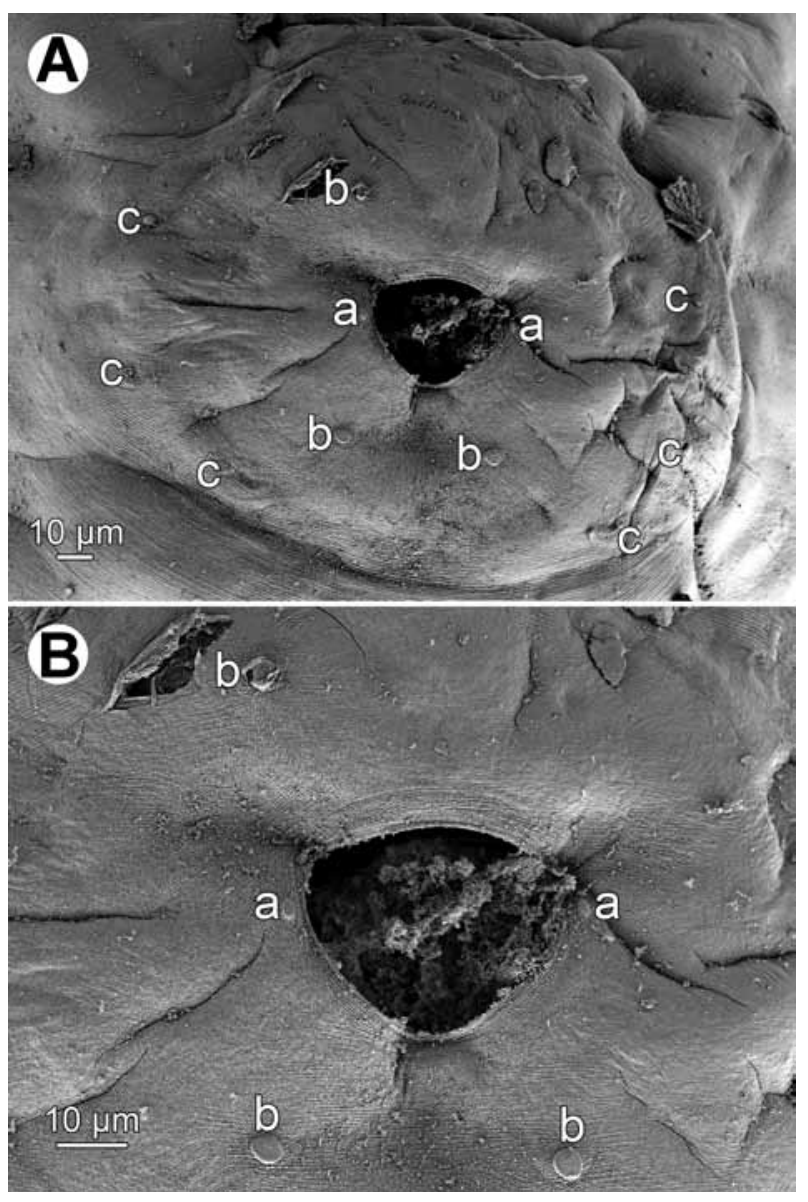

Fig. 2. Philometra lobotidis sp. n., scanning electron micrographs of gravid female. A - cephalic end, apical view; B - region of oral aperture, apical view. Abbreviations: a - lateral cephalic papilla of internal circle; $b$ - submedian cephalic papilla of internal circle; $\mathrm{c}$ - submedian cephalic papilla of external circle.

the Black Sea (Moravec 2006) was reported by Linton (1901) from Lobotes surinamensis from the Atlantic Ocean off the coast of Massachussets, USA, but this determination was considered to be doubtful (Petter and Radujković 1986, 1989, Moravec 2006). It may well be that the specimens recorded by Linton (1901) belonged in fact to $P$. lobotidis sp. n.

\section{Philometra javaensis sp. $\mathrm{n}$.}

Figs. 3, 4

Description (4 gravid specimens; measurements of 3 subgravid specimens in parentheses): Body of fixed specimens yellowish to brownish, filiform, 49-54 (33-39) $\mathrm{mm}$ long and 1.27-2.22 (0.90-1.16) mm in maximum width; maximum width/length ratio of body 1:24-39 (1:29-39). Anterior part of body slightly broader than posterior part; width of cephalic end 190-299 (204-231), that of caudal end 272-503 (245-272). Cuticle smooth. Cephalic end rounded, cephalic papillae indistinct in lateral view (Figs. 3A,B, 4A). Oral aperture circular, relatively small, surrounded by narrow ring of distinctly elevated cuticle. Bottom of mouth formed by three flat oesophageal lobes, each of them with many small denticles on surface (Fig. $4 \mathrm{D}, \mathrm{F})$. Cephalic papillae small, rounded, arranged in two circles. External circle formed by four pairs of submedian papillae; papillae of each pair relatively far from each other. Internal circle represented only by one lateral pair of papillae near oral aperture, usual submedian papillae of internal circle not observed (Figs. 3C, 4A-F). Lateral amphids indistinct. Oesophagus muscular, inflated at anterior end to form distinct bulb, 1.37-1.50 (1.09-1.33) mm long, representing $3(3-4) \%$ of body length. Oesophageal bulb $150-163$ (126-177) long and $163(108-163)$ wide, funnelshaped, with spacious lumen, distinctly separated from more posterior part of oesophagus. Greater, posterior part of oesophagus slightly expanded. Dorsal oesophageal gland not well demarcated, rather small, its poorly visible nucleus at 816-966 (707-857) from anterior end of body. Small ventriculus 39-54 (39-48) long and 66-99 (63$108)$ wide, opening into intestine through valve. Nerve ring encircling oesophagus 286-326 (272-299) from anterior extremity (Fig. 3A). Intestine brown, straight, displaced laterally by uterus and extending posteriorly nearly to posterior extremity; anterior end of intestine relatively narrow; posterior end of intestine atrophied, forming ligament 163-408 (245-408) long attached ventrally to body wall close to posterior extremity. Posterior end of body rounded, without any caudal projections (Fig. 3D). Ovaries short, situated near anterior and posterior body ends. Uterus occupying major part of body, filled with numerous larvae and eggs (only with eggs in subgravid specimens). Larvae 318-393 long, maximum width 15; oesophagus $75-90$ long (21-25\% of body length), length of tail 81-90 (22-27\%) (Fig. 3E).

Male: Unknown.

Type host: Immaculate puffer Arothron immaculatus (Bloch et Schneider) (Tetraodontidae, Tetraodontiformes) (body length $23 \mathrm{~cm}$ ).

Site of infection: Abdominal cavity.

Type locality: Indian Ocean off Pelabuhan Ratu, south coast of western Java, Indonesia (collected 26 November 2001).

Prevalence and intensity: 1 fish intected/1 fish examined; 9 specimens.

Deposition of type specimens: Holotype (MZBNa 517) and 5 paratypes (MZBNa 518) in the Museum Zoologi Bogor, Lembaga Ilmu Pengetahuan Indonesia, Cibinong, Indonesia. One paratype (N-985) in the Institute of Parasitology, Biology Centre, Academy of Sciences of the Czech Republic, České Budějovice, Czech Republic.

Etymology: The specific name of this nematode relates to the region of its origin, i.e., Java (Indonesia).

Remarks. It has been mentioned above that philometrids exhibit a relatively high degree of host specificity and individual species are characterized by their location in the host, particularly that of the gravid females. So 

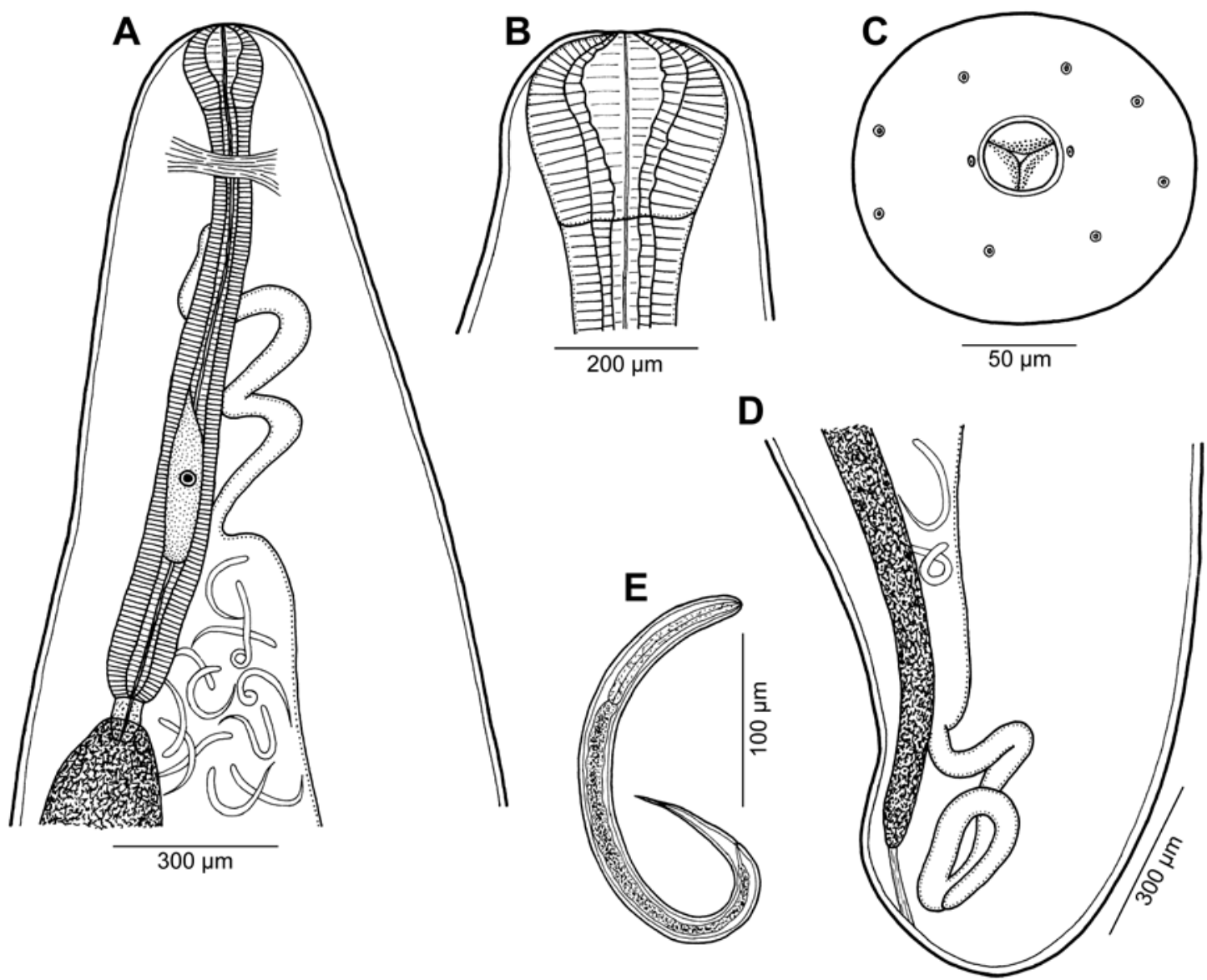

Fig. 3. Philometra javaensis sp. n., gravid female. A - anterior end of body, lateral view; $\mathbf{B}, \mathbf{C}$ - cephalic end, lateral and apical views, respectively; $\mathbf{D}$ - posterior end of body, lateral view; $\mathbf{E}$ - larva from uterus, lateral view.

far, only five nominal species of Philometra are reported from tetraodontiform fishes (see Moravec 2006, Moravec and Justine 2008): P. balistii Rasheed, 1963 from the oculo-orbit of Abalistes stellaris (Bloch et Schneider) and Balistes sp. (both Balistidae) from the Indian Ocean and the Red and South China Seas (Rasheed 1963, Parukhin 1971, 1989), and P. pellucida (Jägerskiöld, 1893) from Arothron stellatus (Bloch et Schneider) from the Java Sea off Indonesia, P. robusta Moravec, Möller et Heeger, 1992 from Arothron mappa (Lesson) off the Philippines, P. thaiensis Moravec, Fiala et Dyková, 2004 from two freshwater species of Tetraodon in Thailand and P. lagocephali Moravec et Justine, 2008 from Lagocephalus sceleratus from the South Pacific off New Caledonia (Jägerskiöld 1894, Moravec et al. 1992, 2004, Moravec and Justine 2008); all the last four-named species were located in the fish abdominal cavity and all their hosts belong to the family Tetraodontidae. Unfortunately, all species described from Tetraodontiformes are known by their females only, whereas conspecific males have not yet been discovered.

Philometra balistii can be easily differentiated from the new species by its female morphology (presence of four large cephalic lobes and markedly large caudal projections) and the site of infection in the host (oculo-orbit vs. abdominal cavity). On the other hand, the morphology (structure of cephalic and caudal ends and of oesophagus, short ovaries, length of larvae in uterus) of the species described from Tetraodontidae is rather similar to that of $P$. javaensis sp. n. and the location of females in the host is identical. However, $P$. pellucida and $P$. robusta differ from $P$. javaensis in a much longer body of gravid females (132-360 and 275-450 mm, respectively, vs. $49-54 \mathrm{~mm})$, maximum width of body (2-5 and $8-10 \mathrm{~mm}$, respectively, vs. $1.27-2.22 \mathrm{~mm}$ ) and a relative length of the oesophagus to body length $(0.6$ and $0.6-0.9 \%$, respectively, vs. $3 \%) ; P$. robusta also differs in the number (14 vs. 10) and arrangement of cephalic papillae and in the presence of small caudal projections.

In contrast to the new species, both $P$. lagocephali and $P$. thaiensis possess 14 (vs. 10) cephalic papillae, the papillae of the external pairs are closer to each other and neither a ring of elevated cuticle around the oral aperture nor denticles on the anterior oesophageal lobes were observed in them; moreover, P. lagocephali differs in having a large, well-developed oesophageal gland (vs. very small, 

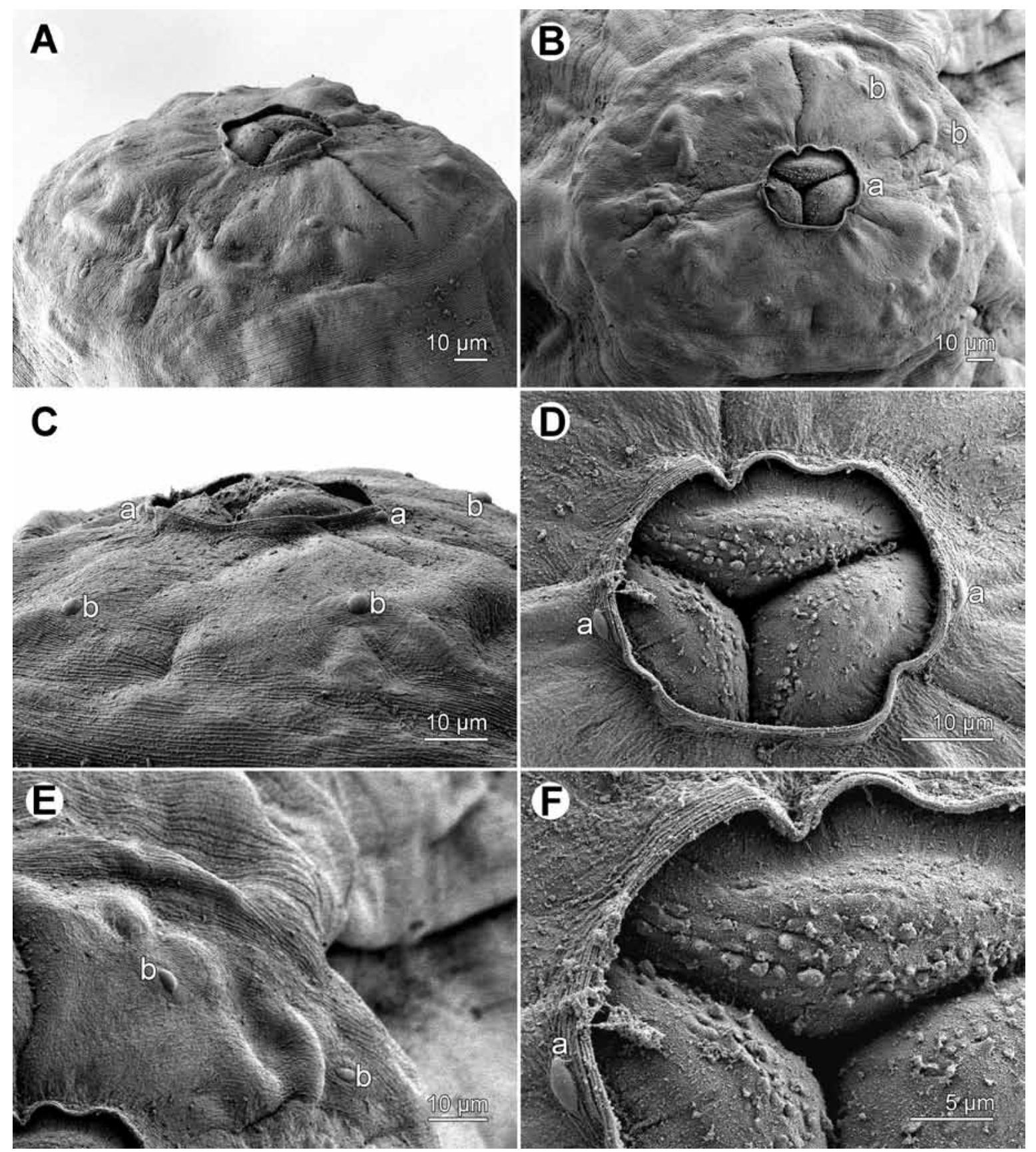

Fig. 4. Philometra javaensis sp. n., scanning electron micrographs of gravid female. A, B - cephalic end, sublateral and apical views; C, D - region of oral aperture, sublateral and apical views (note ring of elevated cuticle surrounding mouth and numerous small denticles on oesophageal lobes); $\mathbf{E}$ - enlarged region of external cephalic papillae, apical view; $\mathbf{F}$ - enlarged region of oral aperture. Abbreviations: $\mathrm{a}$ - lateral cephalic papilla of internal circle; $\mathrm{b}$ - submedian cephalic papilla of external circle.

poorly demarcated), whereas $P$. thaiensis in possessing the anterior oesophageal bulb without a wide lumen and in the environment of the hosts (freshwater vs. marine). Differences of $P$.javaensis from other congeneric species parasitic in the host's body cavity are evident from the key provided by Moravec et al. (2008).

Philometra javaensis is very interesting in that the anterior oesophageal lobes in the mouth of its gravid females bear many small sclerotized denticles (Fig. 4D,F). To date, this feature has not been described for any philometrid species, but only recently it has been observed in Philometroides moraveci Vismanis et Yunchis, 1994, a parasite of subcutaneous tissues of the perciform fish Percottus glenii Dybowski in the Far East, Russia (personal communication of G. S. Sokolov, Moscow). Apparently, the presence/absence of such oesophageal denticles in gravid females may be an important taxonomical feature for the identification of philometrid species. 

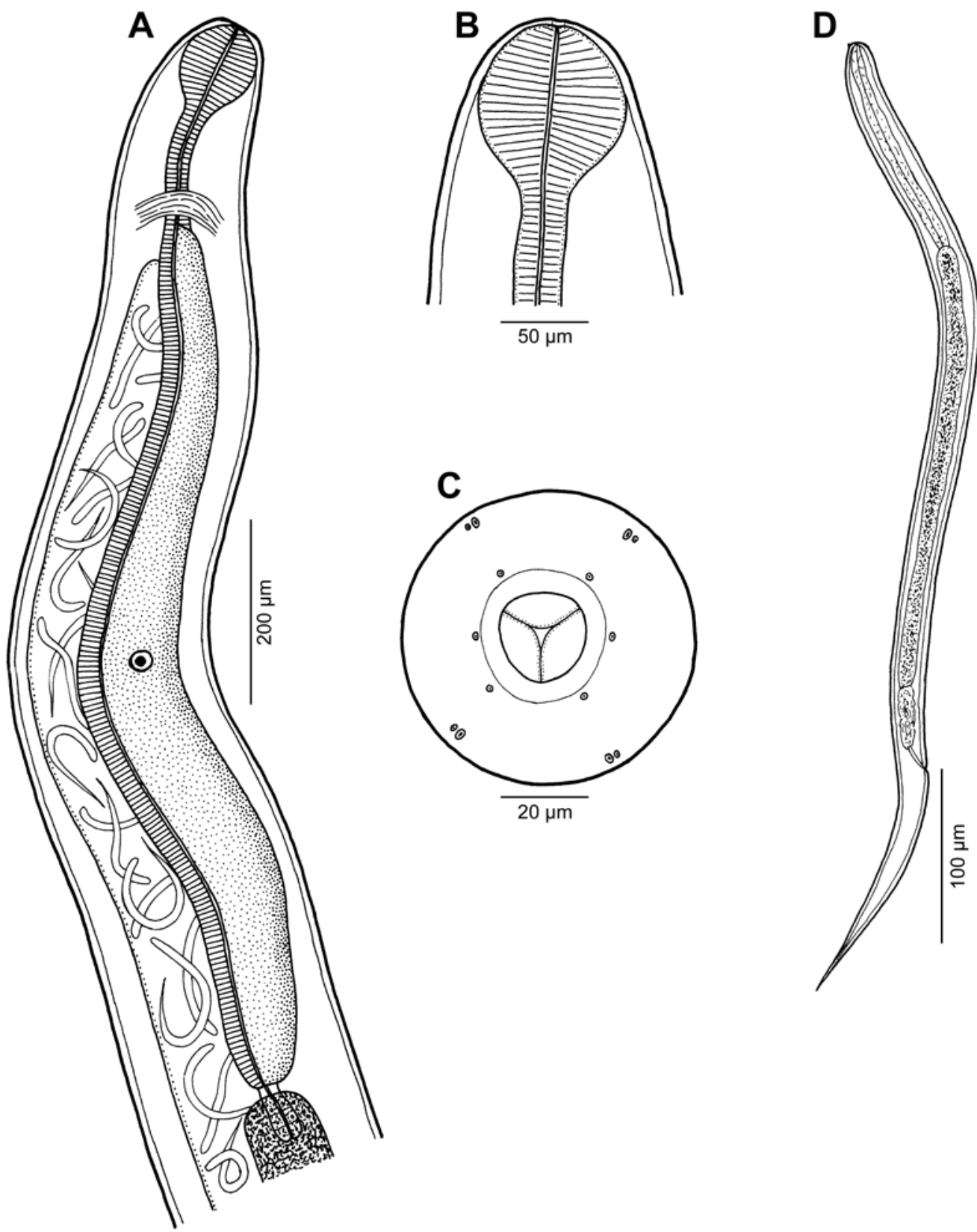

官

Fig. 5. Philometra psettoditis sp. n., gravid female. A - anterior end of body, lateral view; B, C - cephalic end, lateral and apical views; $\mathbf{D}$ - larva from uterus.

\section{Philometra psettoditis sp. $\mathrm{n}$.}

Figs. 5, 6

Description (1 gravid specimen without caudal end, holotype; measurements of body fragment of another specimen in parentheses): Body of fixed specimens yellowish to brownish, filiform, 68 (99) $\mathrm{mm}$ long and 299 (272) in maximum width; maximum width/length ratio of body approximately 1:330. Width of cephalic end 95 . Cuticle finely rugged, almost smooth, without any distinct bosses. Cephalic end rounded, cephalic papillae indistinct in lateral view (Fig. 5A,B). Oral aperture almost circular. Bottom of mouth formed by three flat oesophageal lobes. Cephalic papillae very small, arranged in two circles: ex- ternal circle formed by four pairs of submedian papillae, internal circle consisting of six papillae (four submedian and two lateral) surrounding oral aperture (Figs. 5C, 6A,B). Lateral amphids indistinct. Oesophagus muscular, inflated at anterior end to form distinct bulb, $1.35 \mathrm{~mm}$ long, representing about $1.4 \%$ of body length. Oesophageal bulb spherical, 96 long and 78 wide, not separated from more posterior part of oesophagus. Greater, posterior part of oesophagus slightly expanded medially. Dorsal oesophageal gland large, well demarcated; its nucleus at 802 from anterior end of body. Small ventriculus 9 long and 30 wide present, opening into intestine through valve. 

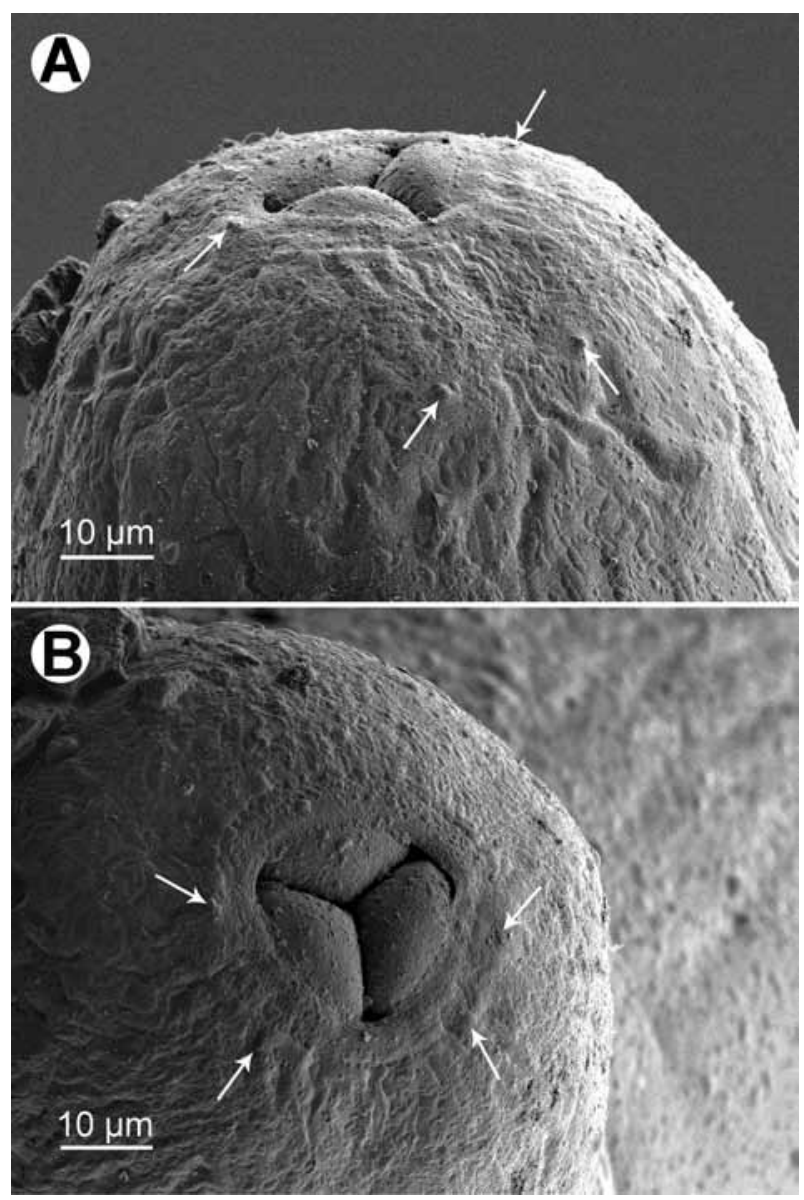

Fig. 6. Philometra psettoditis sp. n., scanning electron micrographs of cephalic end of gravid female. A - sublateral view (arrows indicate cephalic papillae); B - apical view (arrows indicate cephalic papillae).

Nerve ring encircling oesophagus 326 from anterior extremity (Fig. 5A). Intestine brown, straight, displaced laterally by uterus; anterior end of intestine relatively narrow. Posterior end of body missing. Anterior ovary reflexed, long and narrow. Uterus extending anteriorly nearly to level of nerve ring, filled with numerous larvae. Larvae 498-582 long, maximum width 15-18; oesophagus $126-144$ long (22-28\% of body length), length of tail 105-183 (20-37\%) (Fig. 5D).

Male: Unknown.

Type host: Indian spiny turbot, Psettodes erumei (Bloch et Schneider) (Psettotidae, Pleuronectiformes) (body length $40 \mathrm{~cm})$.

Site of infection: Musculature.

Type locality: Indian Ocean off Pelabuhan Ratu, south coast of western Java, Indonesia (collected 30 April 2000).

Prevalence and intensity: 1 fish infected/10 fish examined; 2 specimens.

Deposition of type specimens: Holotype (mounted on SEM stub) (N-986) in the Institute of Parasitology, Biology Centre, Academy of Sciences of the Czech Republic,
České Budějovice, Czech Republic. One paratype (a female body fragment) (MZBNa 519) in the Museum Zoologi Bogor, Lembaga Ilmu Pengetahuan Indonesia, Cibinong, Indonesia.

Ety mology: The specific name of this nematode relates to the genitive form of the generic name of the host.

Remarks. The general morphology of the present specimens found in the body musculature of Psettodes erumei corresponds to the diagnosis of Philometra (see Rasheed 1963, Moravec 2006). As mentioned above, species of this genus, as well as those of other philometrid genera, exhibit a relatively high degree of host specificity and, moreover, individual species are characterized by their location in the host, particularly that of gravid females (Ivashkin et al. 1971, Moravec 2006, Quiazon et al. 2008).

According to Moravec and Bakenhaster (2010), at present there are 14 species of Philometra with gravid females parasitic in the musculature, subcutaneous tissues, fins and gill covers or gill arches of brackish-water and marine fishes. However, most of these species are parasites of fishes belonging to Beloniformes, Scorpaeniformes, Siluriformes, Perciformes and one unidentified fish (reported as "white fish") (Moravec and Bakenhaster 2010). From fishes belonging to Pleuronectiformes, the following four nominal species of Philometra were reported: P. beninensis Obiekezie, 1986 (only juvenile forms), P. fusca (Rudolphi, 1819), P. globiceps (Rudolphi, 1819), P. lateolabracis (Yamaguti, 1935) and P. overstreeti Moravec et de Buron, 2006 (see Moravec 2006).

However, P. fusca is a poorly described species from the abdominal cavity of Bothus mancus (Broussonet) [= misidentified B. podas (Delaroche)? - see Moravec 2006] (Bothidae) from the Tyrrhenian Sea near Italy (Rudolphi 1819), whereas $P$. globiceps and P. lateolabracis are parasites of gonads (the former species allegedly also in the abdominal cavity) mainly of other fishes belonging to Perciformes; the type host of P. globiceps is Uranoscopus scaber (Uranoscopidae, Perciformes) in the seas of the Mediterranean region and in the Black Sea. The records of this parasite from pleuronectiform fishes of the Bothidae, Citharidae and Scophthalmidae in Montenegro and Italy (Petter and Radujković 1986, 1989, Moravec 2006) need to be verified; in view of the papers by Quiazon et al. (2008) and Moravec (2008), records of the gonad-infecting species $P$. lateolabracis from the abdominal cavity or gonads of pleuronectiform fishes in the Philippines (Schmidt and Kuntz 1969) and from the Arabian Sea (Kardousha 1999) are evidently based on misidentifications; adults of $P$. beninensis are parasitizing the fins and subcutaneous tissues of a perciform fish near the Atlantic coast of Nigeria (Obiekezie et al. 1992). Consequently, $P$. overstreeti, occurring in capsules among teeth of the southern flounder Paralichthys lethostigma Jordan et Gilbert in the estuarine system of South Carolina, USA, 
is so far the only relatively well described species of $P h i-$ lometra parasitic in flatfishes as adults.

Philometra overstreeti, as well as $P$. beninesis, can be easily distinguished from the new species by the presence of eight conspicuously large cephalic papillae of the external circle (vs. all cephalic papillae very small) in gravid female; also by the location in the host, host family, and the geographical distribution. Philometra fusca can be distinguished by the location in the host (abdominal cavity vs. musculature), host family (Bothidae vs. Psettodidae) and geographical distribution (Italy vs. Indonesia), whereas $P$. globiceps by the length of the oesophagus of gravid female ( 0.9 vs. $1.35 \mathrm{~mm})$, host order (Perciformes vs. Pleuronectiformes), location in the host (gonads vs. musculature), and geographical distribution (Mediterranean and Black Seas, Europe vs. Indonesia) (see Moravec 2006).

Consequently, the present specimens from $P$. erumei are considered to represent a new species, $P$. psettoditis $\mathrm{sp}$. $\mathrm{n}$. The authors are aware of the fact that it is being in fact described from a single specimen, a procedure that cannot be generally recommended. However, in this case, the new species appears to be well established and, therefore, they consider it more reasonable and useful to give it a specific name rather than to report it only as Philometra sp.

Psettodes erumei was reported to be the host of $P$. lateolabracis in the Arabian Gulf (Kardousha 1999), and previously also Parukhin (1989) indicated that Philometra sp. of Parukhin and Chikunova (1964) from this host in the South China Sea was referable to P. lateolabracis. However, as mentioned above, the records of $P$. lateolabracis, a specific gonad-infecting parasite of the perciform fish Lateolabrax japonicus (Cuvier) in Japan (Quiazon et al. 2008), from $P$. erumei were evidently misidentifications. Considering the parasite's location in the host (mainly fish gonads or abdominal cavity), these nematodes probably belonged to more than one undescribed species of Philometra, but different from P. psettoditis. An unidentified philometrid, Philometra sp., was reported from P. erumei by Bijukumar (1997) from the Arabian Sea off the southwestern Indian coast. Accordingly, P. psettoditis sp. $\mathrm{n}$. is the first nominal species of Philometra parasitizing this fish host.

\section{Philometroides indonesiensis sp. $\mathrm{n}$.}

Figs. 7, 8

Female (1 gravid specimen): Body of fixed specimen gray-coloured with dark-brown intestine visible through cuticle, filiform, $143 \mathrm{~mm}$ long and $1.32 \mathrm{~mm}$ in maximum width; maximum width/length ratio of body $1: 108$. Anterior part of body broader than posterior part; body broadest just posterior to oesophagus; width of posterior part of body 789; width of cephalic end 190, that of caudal end 435. Body with sparsely distributed small cuticular bosses on surface; embossment starts anteriorly at oesophageal region and extends posteriorly to body end; bosses 9-12 high (Figs. 7C,D,F, 8C,D). Cephalic end rounded, cephalic papillae indistinct in lateral view (Fig. 7A,D). Oral aperture large, oval. Bottom of mouth formed by three flat oesophageal lobes. Cephalic papillae small, arranged in two circles: external circle formed by four pairs of submedian papillae, internal circle consisting of six papillae (four submedian and two lateral) surrounding oral aperture (Figs. 7B, 8A,B). Lateral amphids indistinct. Oesophagus muscular, inflated at anterior end to form distinct bulb, $1.16 \mathrm{~mm}$ long, representing $0.8 \%$ of body length. Oesophageal bulb well developed, 129 long and 135 wide, not separated from more posterior part of oesophagus. Greater, posterior part of oesophagus slightly expanded medially. Oesophageal gland starting just posterior to nerve ring and extending posteriorly to end of oesophagus; nucleus of oesophageal gland situated 639 from anterior end of body. Small ventriculus 41 long and 68 wide, opening into intestine through valve. Nerve ring encircling oesophagus 177 from anterior extremity (Fig. 7D). Intestine dark-brown, straight, displaced laterally by uterus and extending posteriorly nearly to posterior extremity; anterior end of intestine wide; posterior end of intestine atrophied, forming short ligament 422 long attached ventrally to body wall close to posterior extremity. Posterior end of body rounded, without any caudal projections (Fig. 7C). Ovaries short, situated near anterior and posterior body ends (Fig. 7C,D). Uterus occupying major part of body, anteriorly extending to level of midlength of oesophagus and posteriorly to end of intestine, filled with numerous larvae and eggs. Larvae 462-480 long, maximum width 12-15; oesophagus 144-147 long, representing $31-32 \%$ of body length, length of tail 126 168 , representing $27-36 \%$; intestines of larvae conspicuously dark-coloured (Fig. 7E).

Male: Unknown.

Type host: Hound needlefish, Tylosurus crocodilus crocodilus (Péron et Lesueur) (Belonidae, Beloniformes).

Site of infection: Musculature.

Type locality: Indian Ocean off Pelabuhan Ratu, south beach of western Java, Indonesia (collected 3 April 2000).

Prevalence and intensity: 1 fish infected/5 fish examined; 1 specimen.

Deposition of type specimen: Holotype (mounted on SEM stub) (N-987) in the Institute of Parasitology, Biology Centre, Academy of Sciences of the Czech Republic, České Budějovice, Czech Republic.

Etymology: The specific name of this nematode relates to the country of its origin, i.e., Indonesia.

Remarks. By the general morphology, in particular the presence of irregularly scattered cuticular bosses on the body of gravid female, the specimen of the present material may be assigned to the philometrid genus Philometroides Yamaguti, 1935 (see Rasheed 1963, Moravec 2006). Cuticular bosses are also present on females of 

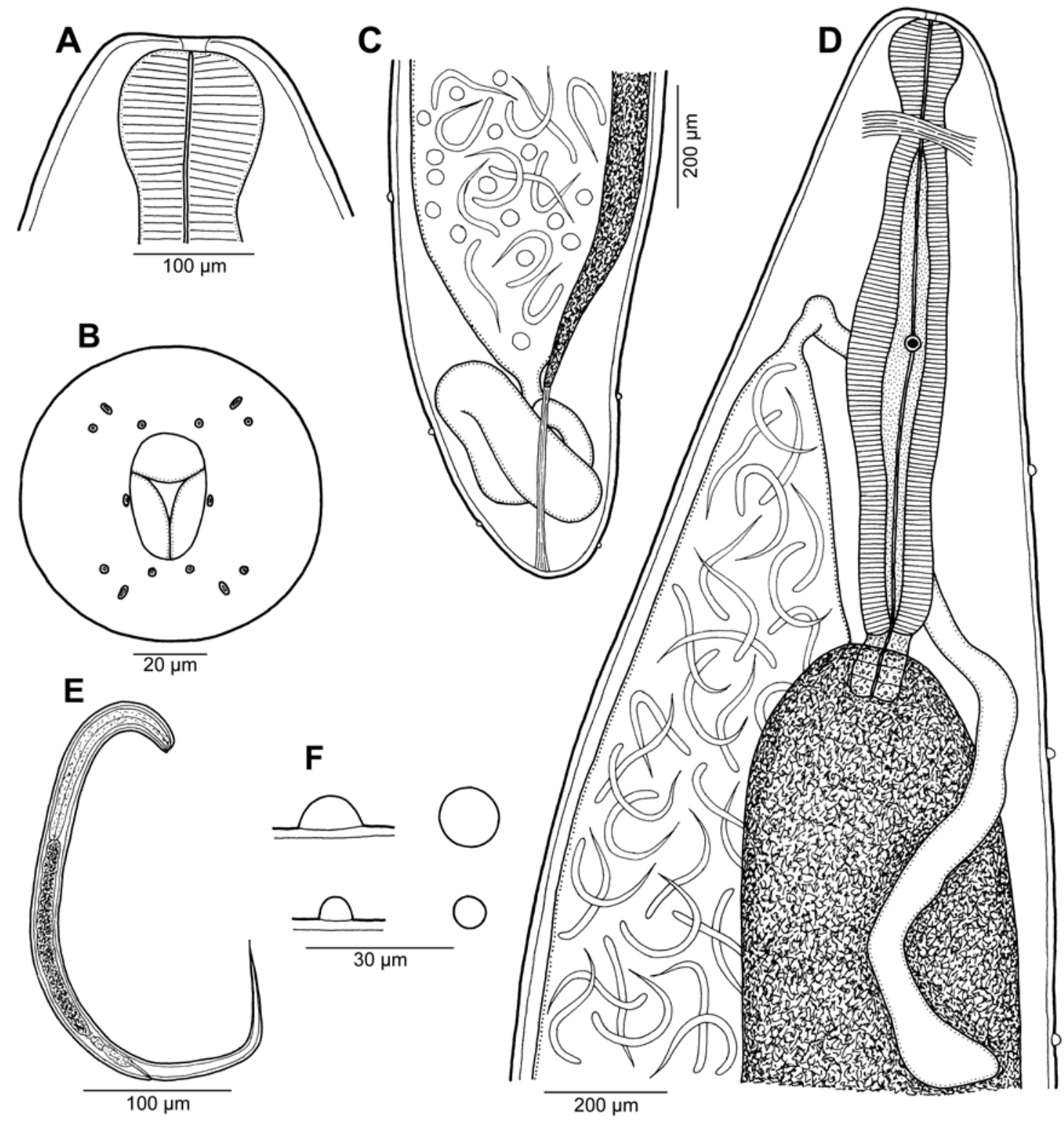

Fig. 7. Philometroides indonesiensis sp. n., gravid female. A, $\mathbf{B}$ - cephalic end, lateral and apical views; $\mathbf{C}$ - posterior end, lateral view; D - anterior end of body, lateral view; $\mathbf{E}$ - larva from uterus, lateral view; $\mathbf{F}$ - cuticular bosses, lateral and apical views.

the monotypic genus Paraphilometroides Moravec et Shahorom-Harrison, 1989 with the only representative in a marine fish, but the structure of its cephalic end is very different form that in Philometroides spp. (see Moravec 2010). Moravec and Nagasawa (2012) reported 27 valid species of Philometroides. Most species of this genus were described only from females, whereas conspecific males are known for eight species. The majority of species (19) occur in freshwater fishes, whereas seven were described from marine fishes and one from a brackishwater fish.

The following species of Philometroides are known as parasites of marine and brackish-water fishes: P. atropi (Parukhin, 1966), P. branchiostegi Moravec et Nagasawa, 2012, P. denticulatus Rasheed, 1965, P. grandipapilla- tus Moravec et Bakenhaster, 2010, P. marinus Moravec et de Buron, 2009, P. oveni Parukhin, 1975, P. paralichthydis Moravec et de Buron, 2006 and P. seriolae (Ishii, 1931); except for P. paralichthydis, they are all parasites of Perciformes (see Moravec 2006, Moravec and de Buron 2009, Moravec and Bakenhaster 2010, Moravec and Nagasawa 2012). Of them, P. denticulatus and P. seriolae, parasites of the body cavity or musculature of Haemulidae, Sciaenidae or Carangidae in the Indian or North Pacific Oceans, differ markedly from the new species in having much longer gravid females (250-320 and 380 $600 \mathrm{~mm}$, respectively, vs. $143 \mathrm{~mm}$ ) and densely scattered cuticular bosses; the former species also by the presence of three oesophageal teeth protruding out of the mouth aperture and distinct caudal projections (Rasheed 1965). 

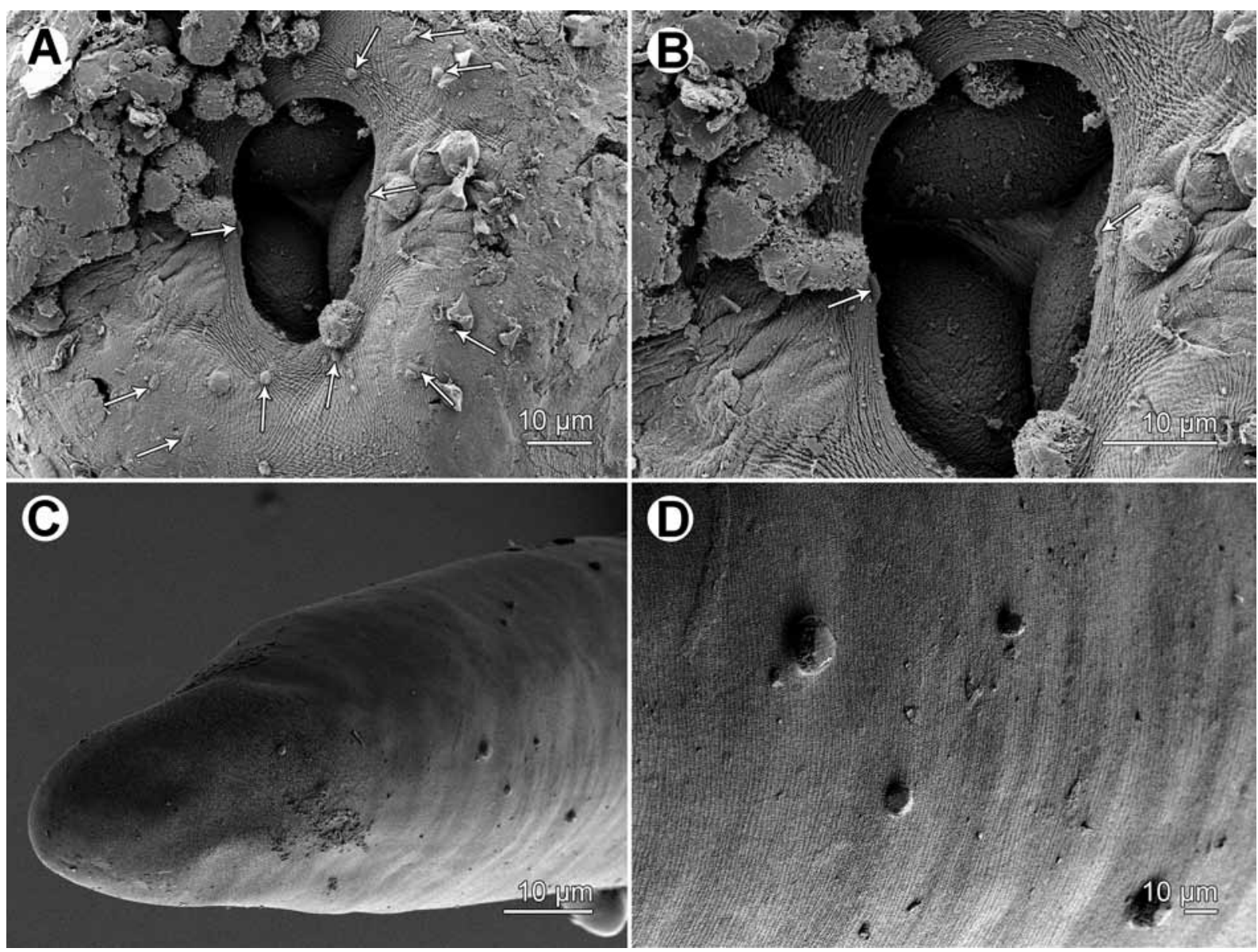

Fig. 8. Philometroides indonesiensis sp. n., scanning electron micrographs of gravid female. A - cephalic end, apical view (arrows indicate cephalic papillae); B - oral aperture, apical view (arrows indicate lateral cephalic papillae of internal circle); $\mathbf{C}-$ posterior end, lateral view (note cuticular bosses); D - cuticular bosses, apical view.

In contrast to $P$. indonesiensis sp. n., the gravid female of P. marinus, a parasite of the body cavity of Rachycentridae in the northern West Atlantic, is much longer $(550 \mathrm{~mm})$ and it is noted for the presence of four large dome-shaped cephalic projections, large caudal projections and the cuticular embossment restricted to the anterior part of the body (Moravec and de Buron 2009). Philometroides atropi from the abdominal cavity of Carangidae in the South China Sea, Gulf of Tonkin (Vietnam) and the Red Sea differs in the absence of the anterior oesophageal bulb, presence of a large oesophageal gland, character of cuticular embossment and in the shape of the cephalic region (markedly protruding out from the remaining part of body), whereas P. oveni, a parasite of the oculo-orbit and eye of Serranidae in the Mediterranean Sea, mainly in possessing a large oesophageal gland, densely scattered cuticular bosses and a shorter body $(25-35 \mathrm{~mm})$ (Parukhin 1966, 1975).

The female body of $P$. branchiostegi, P. grandipapillatus and $P$. paralichthydis, parasites of head tissues and fins of Malacanthidae, Rachycentridae or Paralichthyidae in the western North Pacific or the western North
Atlantic, is distinctly shorter $(18,20-45$ and $11-29 \mathrm{~mm}$, respectively, vs. $143 \mathrm{~mm}$ ) and the external cephalic papillae of these species are markedly big, fleshy (vs. small); moreover, P. branchiostegi and P. paralichthydis have cuticular bosses densely covering the body (vs. sporadically) (Moravec and de Buron 2006, Moravec and Bakenhaster 2010, Moravec and Nagasawa 2012). The distinctions between $P$. indonesiensis and congeneric species parasitizing freshwater fishes are evident from the key to Philometroides spp. provided by Moravec (2006) and from data on the two North American species P. aphanonaris Moravec, Crosby, de Buron, González-Solís et Roumillat, 2008 and P. wellborni Moravec, Crosby, de Buron, González-Solís et Roumillat, 2008 subsequently described from centrarchids (Moravec et al. 2008).

Fishes of the family Belonidae (needlefishes) seem to be frequent hosts of philometrid nematodes, but to date only representatives of the genus Philometra have been recorded in them (see Moravec 2006, Moravec and Bakenhaster 2012). Moravec and Ali (2005) described Philometra tylosuri Moravec et Ali, 2005 based on nongravid females found in the musculature and subcutaneous tis- 
sues of Tylosurus crocodilus crocodilus in the Persian Gulf off the coast of Iraq, which is morphologically somewhat similar to the new species. Since the site in the host and the host species of both nematodes are identical, it cannot be excluded that subsequent studies will prove the conspecificity of both philometrid species; it may well be that cuticular bosses are present only on the body of gravid females, in which, on the contrary, small caudal projections are no longer present. However, due to existing morphological and biometrical differences between both these nematode forms, for the time being we consider it more reasonable to establish a separate species for the specimen of the present material. Petersen et al. (1993) reported Philometra sp. gravid females up to $18 \mathrm{~cm}$ long from the musculature of $T$. crocodilus crocodilus in Philippine waters (see also Arthur and Lumanlan-Mayo 1997) and Philometra sp. was also reported from the musculature of the same fish host species off the southern coast of Java, Indonesia (Jacob and Palm 2006); it is highly probable that both these forms were conspecific with $P$. indonesiensis sp. n. (sporadically distributed cuticular bosses can be easily overlooked in this species).

\section{Philometroides trichiuri sp. n.}

Figs. 9, 10

Gravid female (6 specimens from Trichiurus lepturus, measurements of holotype in parentheses; measurements of 2 specimens from Lepturacanthus savala in brackets): Body of fixed specimens yellowish to brownish, filiform, 13.0-22.4 (22.4) [12.0-18.9] mm long and 394-1 225 (1 225) [870-925] in maximum width; maximum width/length ratio of body $1: 18-33$ (1:18) [1:14-20]. Anterior part of body broader than posterior part; width of cephalic end 177-272 (258) [204-286], that of caudal end 95-163 (150) [136-163]. Body of larger specimens densely covered with small transparent cuticular excrescences appearing as papilla-like on body sides, but in fact represented by small circular to transversely oval bosses and transverse mounds in apical view (Figs. 9A-D,F,J, 10D-F); this cuticular ornamentation starts anteriorly at level of anterior oesophageal bulb, being, however, more distinct on posterior part of body. Group of several papilla-like bosses present at top of caudal end (Figs. 9I, 10E); ornamentation poorly visible or indistinct on small specimens. Cephalic end rounded, cephalic papillae indistinct in lateral view (Fig. 9A). Oral aperture circular, large. Oesophageal lobes not completely separated from each other in apical view, somewhat elevated. Cephalic papillae very small, difficult to observe, arranged in two circles: external circle formed by four pairs of submedian papillae, internal circle consisting of six papillae (four submedian and two lateral) surrounding oral aperture (Figs. 9H, 10A-C). Lateral amphids indistinct. Oesophagus muscular, inflated at anterior end to form large bulb, 734-925 (911) [983-1 142] long, representing 4-6 (4) [6-8]\% of body length. Oesophageal bulb spherical, conspicuously large, 136-204 (204) [195-245] long and 150-204 (190) [174-204] wide, distinctly separated from more posterior part of oesophagus. Greater, posterior part of oesophagus slightly expanded medially. Dorsal oesophageal gland well developed, starting just posterior to nerve ring and extending posteriorly to end of oesophagus; nucleus of oesophageal gland conspicuous, situated 504-612 (612) [653-680] from anterior end of body. Small ventriculus 21-30 (21) [15-30] long and 27-36 (27) [36-39] wide, opening into intestine through valve. Nerve ring encircling oesophagus 177-258 (258) [245-299] from anterior extremity (Fig. 9A,G). Intestine brownish, straight, displaced laterally by uterus and extending posteriorly nearly to posterior extremity; anterior end of intestine relatively narrow; posterior end of intestine atrophied, forming ligament 313-544 (544) [272-286] long attached ventrally to body-wall close to posterior extremity (Fig. 9B,C). Posterior end of body rounded, without any caudal projections (Figs. 9D,I, 10E). Ovaries short, situated near anterior and posterior body ends (Fig. 9A-C). Uterus occupying major part of body, anteriorly extending to level of nerve ring, filled with numerous larvae and eggs. Larvae 405-438 (not measured) [402-489] long, maximum width 15 [1215]; oesophagus 129-138 [135-144] long, representing $30-34[29-34] \%$ of body length, length of tail 114-147 [93-147], representing 28-35 [23-31]\% (Fig. 9E).

Subgravid female (2 specimens from $T$. lepturus; measurements of 4 specimens from L. savala in brackets): Body 3.55-6.60 [4.33-9.71] mm long, 163-272 [231408] wide; maximum width/length ratio of body 1:22-24 [1:19-26]. Width of cephalic end 95-150 [136-163], that of caudal end 68-95 [95-109]. Ornamentation on cuticle indistinct (Fig. 9G). Oesophagus 571-666 [707-789] long, representing 10-16 [8-17]\% of body length. Oesophageal bulb 95-122 [136-162] long and 82-122 [109-150] wide. Nucleus of oesophageal gland 381-462 [340-476] from anterior end of body. Ventriculus 15 [15-21] long, 24 [36-39] wide. Nerve ring 122-163 [163-177] from anterior extremity. Ligament 197-231 [114-313] long. Posterior end of body rounded, without any caudal projections. Uterus filled with numerous eggs.

Nongravid female (2 specimens from $L$. savala): Body 2.43-2.64 mm long, 68-109 wide; maximum width/length ratio of body 1:24-36. Width of cephalic end 54-68, that of caudal end 41-54. Cuticle without bosses. Oesophagus 233-544 long, representing 10-21\% of body length. Oesophageal bulb 69-78 long and 45-60 wide. Nucleus of oesophageal gland 126-367 from anterior end of body. Ventriculus 6-12 long, 12-21 wide. Nerve ring 108-111 from anterior extremity. Ligament 99-135 long. Posterior end of body rounded, without any caudal projections. Uterus empty.

\section{Male: Unknown.}

Ty p e host: Largehead hairtail, Trichiurus lepturus Linnaeus (Trichiuridae, Perciformes) (body length 75 and $108 \mathrm{~cm}$ ). 

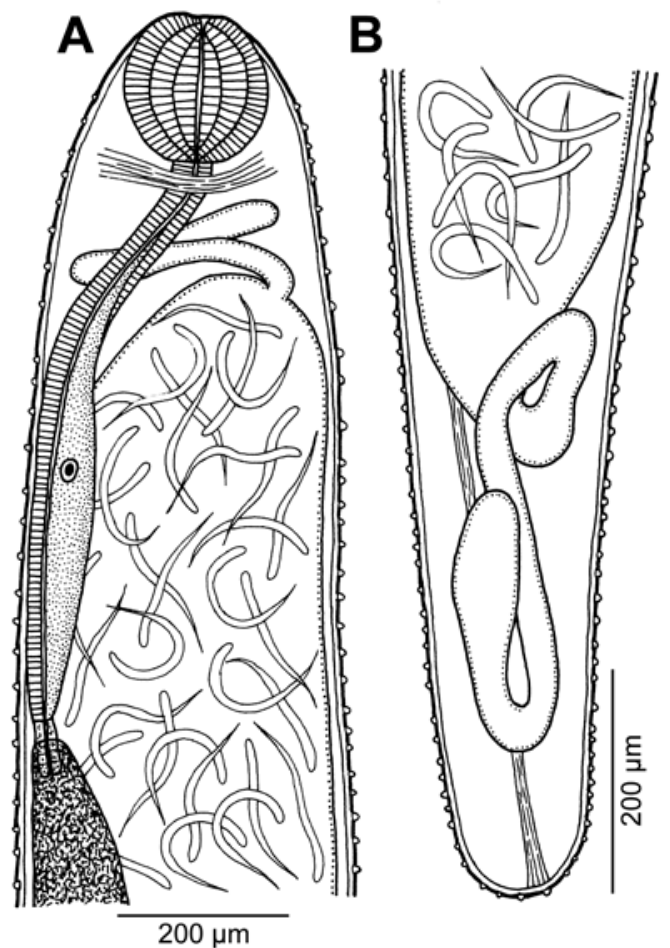

C
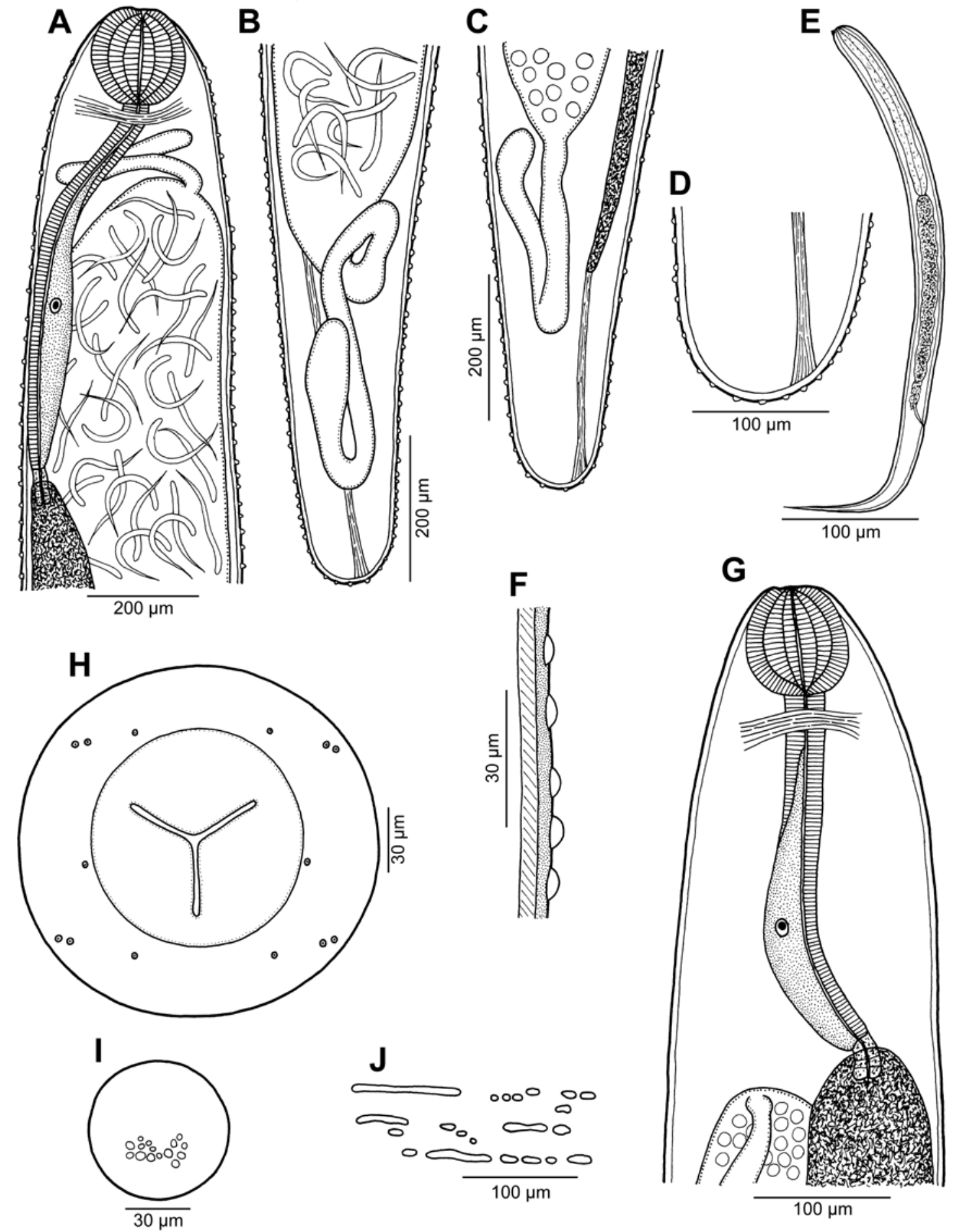

Fig. 9. Philometroides trichiuri sp. n., female. A - anterior end of gravid specimen, lateral view; $\mathbf{B}$ - posterior end of gravid specimen, lateral view; $\mathbf{C}$ - same, other specimen; $\mathbf{D}$ - caudal end of gravid specimen, lateral view; $\mathbf{E}$ - larva from uterus; $\mathbf{F}$ - cuticular ornamentation, lateral view; $\mathbf{G}$ - anterior end of subgravid specimen, lateral view; $\mathbf{H}$ - cephalic end, apical view; I - caudal end, apical view; $\mathbf{J}$ - cuticular ornamentation, apical view. (Based on specimens from Trichiurus lepturus.)

Other host: Savalai hairtail, Lepturacanthus savala $(\mathrm{Cu}-$ vier) (Trichiuridae, Perciformes) (body length 68 and $83 \mathrm{~cm}$ ).

Site of infection: Dorsal fin.

Type locality: Indian Ocean off Pelabuhan Ratu, south beach of western Java, Indonesia [in T. lepturus collected
30 April and 15 July 2000 (including holotype), in L. savala 1 June 2001].

Prevalence and intensity: T. lepturus: 2 fish infected/5 fish examined; 2 and 9 specimens. L. savala: $1 / 5 ; 21$.

Deposition of type specimens: Holotype(MZBNa 


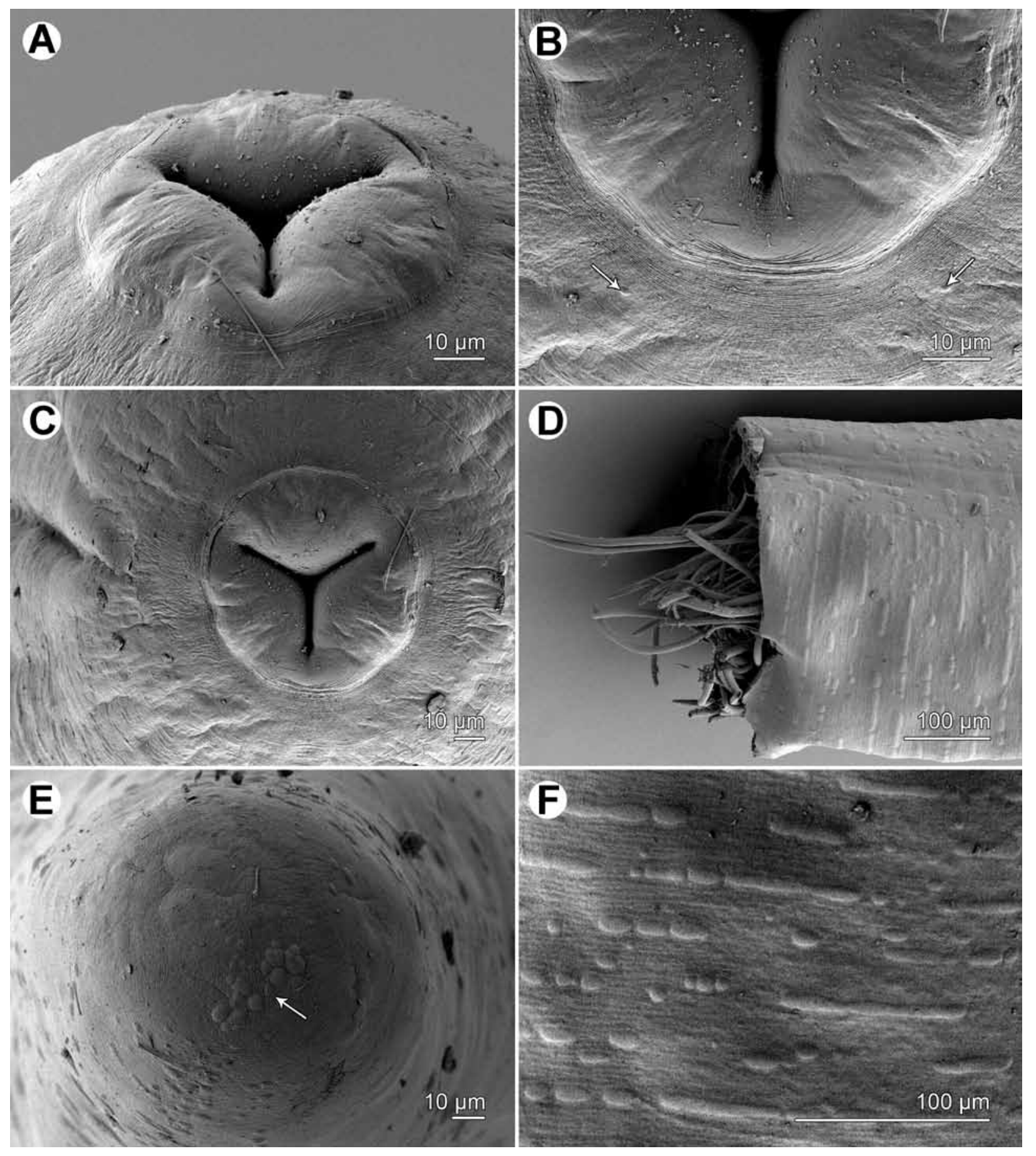

Fig. 10. Philometroides trichiuri sp. n., scanning electron micrographs of gravid female. A - cephalic end, ventral view; B - detail of ventral region of mouth (arrows indicate submedian cephalic papillae of internal circle); C - cephalic end, apical view; $\mathbf{D}$ - broken body with distinct cuticular ornamentation (note protruding larvae); $\mathbf{E}$ - caudal end, apical view (arrow indicates two groups of terminal bosses); $\mathbf{F}$ - cuticular ornamentation on middle part of body. (Based on specimens from Trichiurus lepturus.)

520) and 12 paratypes (MZBNa 521 and MZBNa 522) in the Museum Zoologi Bogor, Lembaga Ilmu Pengetahuan Indonesia, Cibinong, Indonesia. Two paratypes (N-988) in the Institute of Parasitology, Biology Centre, Academy of Sciences of the Czech Republic, České Budějovice, Czech Republic.

Etymology: The specific name of this nematode relates to the genitive form of the generic name of the type host.
Remarks. Of the nine species of Philometroides parasitizing marine and brackish-water fishes (see above), the body of gravid females of four of them, P. denticulatus, $P$. indonesiensis, $P$. marinus and $P$. seriolae, is much longer than that in the new species, exceeding $140 \mathrm{~mm}$ (vs. less than $23 \mathrm{~mm}$ ); moreover, in contrast to the new species, $P$. denticulatus and $P$. marinus possess well- 
developed caudal projections, $P$. indonesiensis only sporadically scattered cuticular bosses, and $P$. seriolae has a moderately developed anterior oesophageal inflation and the length of oesophagus is $4.1-6.0 \mathrm{~mm}$ (vs. about $1 \mathrm{~mm}$ ) (Rasheed 1965, Moravec 2006, Moravec and de Buron 2009, Quiazon et al. 2010). Philometroides branchiostegi, $P$. grandipapillatus and $P$. paralichthydis differ in having conspicuously large, fleshy cephalic papillae (vs. cephalic papillae small) (Moravec and de Buron 2006, Moravec and Bakenhaster 2010, Moravec and Nagasawa 2012), whereas $P$. atropi and $P$. oveni in the missing or poorly developed anterior oesophageal inflation (vs. anterior oesophageal inflation conspicuously large, bulbous) (Parukhin 1966, 1975). Moreover, the cuticular ornamentations of the new species are in form of small bosses and transverse mounds, resembling thus only $P$. paralichthydis, a parasite of subcutaneous tissues and fins of the flatfish Paralichthys lethostigma Jordan et Gilbert in the USA (see Moravec and de Buron 2006).

Philometroides trichiuri is the first species of the genus recorded from fishes of the perciform family Trichiuridae. The only other philometrid nematode reported from the same fish host species as the type host of $P$. trichiuri, i.e., T. lepturus, is Philometra ivaschkini Parukhin, 1976, a species inadequately described from females found in the stomach wall of this fish in the Gulf of Aden (coast of Oman, Masira Bay) and the Indian Ocean near the coast of southeastern Africa (Safala shallow water) (Parukhin 1976). Although some morphological features (e.g., large anterior oesophageal bulb and oesophageal gland) and measurements of $P$. ivaschkini are similar to those of $P$. trichiuri and cuticular ornamentations may be indistinct in small females of the latter species (see above), both forms distinctly differ in the absence/presence of cuticular ornamentations in gravid females, number and arrangement of inner cephalic papillae and the site of infection in the host. Therefore, we consider it reasonable to establish a new species for the nematodes from Indonesia.

Acknowledgements. We are grateful to Dr. Darnas Dana for enabling parasitological collections at IPB Bogor and to Prof. Harry Palm for his support during the work in Indonesia. Authors' thanks are also due to the staff of the Laboratory of Electron Microscopy, Institute of Parasitology, Biology Centre of the ASCR, České Budějovice for their technical assistance, and to Blanka Škoríková of the same Institute for help with illustrations. Collections in Indonesia were supported by the German Academic Exchange Service (DAAD). This study was partly supported by the Czech Science Foundation grant No. P505/12/ G112 and the research project of the Institute of Parasitology, BC ASCR (Z60220518).

\section{REFERENCES}

Arthur J.R., Lumanlan-Mayo S. 1997: Checklist of the Parasites of Fishes of the Philippines. FAO Fisheries Technical Paper 369. FAO, Rome, 102 pp.

Bijukumar A. 1997: Studies on the metazoan parasite communities associated with the flatfishes (order: Pleuronectiformes) of the southwest coast of India. Riv. Parassitol. 13 (Year 1996): 251-269 + 5 Tables.

Froese R., Pauly D. (Eds.) 2011: FishBase. World Wide Web electronic publication, www.fishbase.org, version 08/2011.

Ivashin V.M., Sobolev A.A., Khromova L.A. 1971: [Camallanata of Animals and Man and the Diseases Caused by Them. Osnovy Nematodologii 22.] Nauka, Moscow, 388 pp. (In Russian.)

JACOB E., PALM H.W. 2006: Parasites of commercially important fish species from the southern Java coast, Indonesia, including the distribution pattern of trypanorhynch cestodes. Verhandl. Gesellsch. Ichthyol. 5: 163-191.

JÄGERSKIÖLD L.A. 1893: Bidrag till kännedomen om nematoderna. [Akad. avh. Uppsala]. Stockholm, 86 pp. +6 Plts.

JÄGERSKIÖLD L.A. 1894: Beiträge zur Kenntniss der Nematoden. Zool. Jahrb., Abt. Anat. Ontog. Thiere, 7: 449-532 + Plts. 2628.

Kardousha M.M. 1999: The first record of Philometra lateolabracis Yamaguti, 1935 [sic!] (Nematoda: Spirurida; Philometridae) from teleost fishes of the Arabian Gulf. Qatar Univ. Sci. J. 18: $131-136$.

Kleinertz S. 2010: Fish parasites as bioindicators: Environmental status of coastal marine ecosystems and a grouper mariculture farm in Indonesia. PhD thesis, University of Bremen, Germany, 263 pp. (In German.)
Linton E. 1901: Parasites of fishes of the Woods Hole Region. Bull. U.S. Fish. Comm. 1899: 441-481.

Moravec F. 2004: Some aspects of the taxonomy and biology of dracunculoid nematodes parasitic in fishes: a review. Folia Parasitol. 51: 1-13.

Moravec F. 2006: Dracunculoid and Anguillicoloid Nematodes Parasitic in Vertebrates. Academia, Prague, 634 pp.

Moravec F. 2008: Systematic status of Philometra jordanoi (López-Neyra, 1951) and some other congeneric species previously identified as Philometra lateolabracis (Yamaguti, 1935) (Nematoda: Philometridae). Folia Parasitol. 55: 159-160.

Moravec F. 2010: Structure of the female cephalic end and cuticular ornamentations of Paraphilometroides nemipteri (Nematoda: Philometridae), as revealed by SEM. Folia Parasit. 57: 313-314.

Moravec F., Ali A.H. 2005: Two new species of Philometra (Nematoda: Philometridae) from needlefishes (Belonidae) in Iraq, with a key to Philometra spp. parasitic in the host's subcutaneous tissues, fins and musculature. Folia Parasitol. 52: 267-273.

Moravec F., Bakenhaster M. 2010: Philometrid nematodes infecting fishes from the Everglades National Park, Florida, USA, with description of two new species. Folia Parasitol. 57: 213-222.

Moravec F., Bakenhaster M. 2012: New observations on philometrid nematodes (Philometridae) in marine fishes from the northern Gulf of Mexico and the Indian River Lagoon of Flori$\mathrm{da}$, with first description of the male of Caranginema americanum. J. Parasitol. 98: 398-403.

Moravec F., Crosby M.D., de Buron I., González-Solís D., Roumillat W.A. 2008: Three new species of philometrids 
(Nematoda: Philometridae) from centrarchid fishes in the USA. J. Parasitol. 94: 1103-1113.

Moravec F., de Buron I. 2006: Two new species of philometrid nematodes (Nematoda: Philometridae) from the southern flounder Paralichthys lethostigma in the estuaries of South Carolina, USA. Folia Parasitol. 53: 139-146.

Moravec F., de Buron I. 2009: Two new species of philometrids (Nematoda: Philometridae) from marine fishes off South Carolina. J. Parasitol. 95: 722-727.

Moravec F., Fiala I., Dyková I. 2004: Philometra thaiensis sp. nov. (Nematoda, Philometridae) from Tetraodon palembangensis and T. fluviatilis (Pisces) from fresh waters in Thailand, with a key to Philometra spp. parasitic in the host's abdominal cavity. Acta Parasitol. 49: 319-324.

Moravec F., Gaglio G., Giannetto S., Marino F. 2010: Philometra spicarae sp. n. (Nematoda: Philometridae) from the abdominal cavity of the marine fish (picarel) Spicara smaris (Centracanthidae) off Sicily, Italy. Parasitol. Res. 107: 399-402.

Moravec F., Justine J.-L. 2008: Some philometrid nematodes (Philometridae), including four new species of Philometra, from marine fishes off New Caledonia. Acta Parasitol. 53: 369-381.

Moravec F., Möller H., Heeger T. 1992: Philometra robusta sp. n. (Nematoda: Philometridae) from the abdominal cavity of the scribbled toadfish, Arothron mappa (Lesson) from the Philippines. Folia Parasitol. 39: 227-234.

Moravec F., Nagasawa K. 2012: Two species of philometrid nematodes (Philometridae) from marine fishes off Japan, including Philometroides branchiostegi sp. n. from Branchiostegus japonicus (Malacanthidae). Folia Parasitol. 59: 71-78.

Obiekezie A.I., Anders K., Lick R., Möller H., Palm H. 1992: External lesions and flesh parasites in commercial fishes of Nigerian inshore waters. Aquat. Living Resour. 5: 173-183.

Parukhin A.M. 1966: [Pseudophilometroides atropi gen. et sp. n., a new nematode of the family Dracunculidae Leiper, 1912.] Zool. Zh. 45: 766-767. (In Russian with English summary.)

Parukhin A.M. 1971: [Nematodes from fishes of the Red Sea and Indian Ocean.] In: Voprosy Ekologii Ryb Yuzhnykh Morey, Biologiya Morya 23. Naukova Dumka, Kiev, pp. 177-193. (In Russian.)

Parukhin A.M. 1975: [Philometroides oveni sp. n., a parasite of the sea perch Paracanthopristis hepatus.] Zool. Zh. 54: 312 314. (In Russian with English summary.)
Parukhin A.M. 1976: [Parasitic Worms of Commercial Fishes of the Southern Seas.] Naukova Dumka, Kiev, 183 pp. (In Russian.)

Parukhin A.M. 1989: [Parasitic Worms of Benthic Fishes of the Southern Seas.] Naukova Dumka, Kiev, 154 pp. (In Russian.)

Parukhin A.M., Chikunova D.A. 1964: [Helminth fauna of marine fishes of the family Balistidae from the South China Sea.] Uch. Zap. Gor'kov. Gos. Univ. im. N.I. Lobachevskogo, 62: 100-115. (In Russian.)

Petersen F., Palm H., Möller H., Cuzi M.A. 1993: Flesh parasites of fish from central Philippine waters. Dis. Aquat. Org. 15: 81-86.

Petter A.-J., Radujković B.M. 1986: Nématodes parasites de poissons de la mer Adriatique. Bull. Mus. Natn. Hist. Nat., 4e sér., sect. A, 8: 487-499.

Petter A.-J., Radujković B.M. 1989: Parasites des poissons marrins du Montenegro: nematodes. Acta Adriat. 30: 195-236.

Quiazon K.M.A., Yoshinaga T., Ogawa K. 2008: Taxonomical study into two new species of Philometra (Nematoda: Philometridae) previously identified as Philometra lateolabracis (Yamaguti, 1935). Folia Parasitol. 55: 29-41.

Quiazon K.M.A., Yoshinaga T., Ogawa K. 2010: Taxonomical note on the redescription of Philometroides seriolae (Ishii, 1931) infecting Japanese amberjack (Seriola quinqueradiata Temminck et Schlegel, 1845) in Japan. J. Trop. Biol. 8: 29-34.

RAsheEd S. 1963: A revision of the genus Philometra Costa, 1845. J. Helminthol. 37: 89-130.

Rasheed S. 1965: Additional notes on the family Philometridae Baylis and Daubney, 1926. J. Helminthol. 39: 349-362.

RudolPHi C.A. 1819: Entozoorum synopsis cui accedunt mantesia duplex et indices locupletissimi. S. A. Rücker, Berolini, 811 pp.

Rückert, S., Hagen W. Yuniar A.T., Palm, H.W. 2009: Metazoan fish parasites of Segara Anakan Lagoon, Indonesia, and their potential use as biological indicators. Reg. Environ. Change 9: 315-328.

Rückert S., Klimpel S., Palm H.W. 2010: Parasites of cultured and wild brown-marbled grouper Epinephelus fuscoguttatus (Forsskål, 1775) in Lampung Bay, Indonesia. Aquacul. Res. 41: 1158-1169.

Schmidt G.D., Kuntz R.E. 1969: Nematode parasites of Oceanica. V. Four new species from fishes of Palawan, P. I., with a proposal for Oceanicucullanus gen. nov. Parasitology 59: 389-396. 